\title{
Diane Ravitch \\ Reign of Error: The Hoax of the Privatization Movement and the Danger to American Public Schools
}

New York: Alfred A. Knopf, 2013. 396 pp.

\section{Kate Dubensky \\ University of Victoria}

In her latest book, Reign of Error: The Hoax of the Privatization Movement and the Danger to America's Public Schools, Diane Ravitch offers a critical analysis of the condition of public education in twenty-first century America. Reign of Error begins by seeking to answer the question: "Is American education in crisis?" Ravitch offers a captivating depiction of the corporate and political interests that market what she considers to be the unfounded claim that the nation is at risk. Extending the argument against the high-stakes testing and accountability movement begun in her earlier work, The Death and Life of the Great American School System, Ravitch provides a thorough analysis of empirical and qualitative social science research to investigate the notion that education is in decline and that the reforms currently promoted are well-evidenced as effective enough to improve American schooling.

Ravitch's earlier support for testing and accountability during her tenure as a US Assistant Secretary of Education under George H.W. Bush has given way to a broad critique of current education policy that promotes reform, closure, and privatization as solutions to low-achieving schools. Setting the context for the educational reform movement, Ravitch points to the No Child Left Behind legislation as marking a shift in federal involvement in education, the expansion of its directive role, and its insatiable hunger for high-stakes test scores to fuel the reform model of testing and accountability. In its early chapters, Reign of Error pulls back the curtain to expose how corporate powerhouses fund the campaigns of political allies, who then push through legislation that shifts the domain of public schooling into a new, as yet unexploited, economic free market. Among them, the leading funders include the Bill 
and Melinda Gates Foundation and the Walton Family Foundation, bolstered by the Obama administration's Race to the Top legislation. Ravitch deftly demonstrates the rhetorical spin used to create a culture of fear- "schools at risk" and "a nation in decline", that then implores America to "put students first" and "close the achievement gap." Ravitch convincingly demonstrates how this rhetoric employs a discourse of reform to advance policies of deregulation and privatization.

Re-employing the quantitative data generated from high-stakes testing and accountability, Ravitch offers a compelling alternative to the education in crisis narrative, pointing to the rise in scores across almost all demographics, and rising high school and college graduation rates. Rather, we learn that, through testing, accountability and school closures, American public schooling is being sold off piecemeal to market capitalism and private interests. Instead of providing equity of opportunity, charter schools skim off the easiest to educate students, leaving behind those most in need. Sold as choice, vouchers and charter schools appeal to the American consumer mentality and have been slowly replacing democratically run, community-based public schools with a privately managed, for-profit, free market system.

The impact of Ravitch's argument results from locating educational inequity within the larger socio-economic fabric of twenty-first century America. At the intersection of class and race, the practices of privatization that allow education funding to follow students to the schools of their choice - rather than support communitybased public schools - means less affluent students, those more difficult to educate as a result of the effects of poverty, are most often also racially segregated. One of the most powerful statistics she cites to illustrate this correlation explains that, while one quarter of American children live in poverty, concentrations of poverty are disparate, affecting 12.5 percent of White, 13 percent of Asian, 34 percent of Hispanic, and 37 percent of Black children. After school closures, vouchers and white flight, these racialized concentrations of poor children are left in "apartheid schools" (292), with up to 90 percent of student populations from the most at-risk demographics. Ravitch's warning is clear and compelling - for-profit charter schools are creating a dual system of education - exacerbating the gap between the least and most affluent students

Ravitch successfully argues that the growing achievement gap between less and more affluent students is not a school-based problem, but a social one. As Ravitch explains, rather than accept the reform movement's suggestion that "good" teachers can solve poor academic performance - rhetoric used to advance testing and accountability — substantive change requires addressing the root causes of poverty that result in poor academic performance: lacks of medical care for mothers, wraparound social and health services, early childhood education, and full, rich school curricula. In a scathing critique of the reform agenda and its influence on policy, Ravitch argues, "this is not school reform, nor is it social reform. It is social neglect. It is a purposeful abandonment of public responsibility to address deep seated problems that only public policy can overcome" (298).

At stake in the movement toward privatization is the loss of democratic control of schools, and the equity of educational opportunity that public schooling aims to 
provide. In Reign of Error, Ravitch weaves together complex statistical data, policy analysis, and insider reflection in a remarkably accessible and lively critical analysis. Reign of Error offers an excellent contribution to the current discourse on social inequality in America generally, and on the neo-liberalisation of education in particular, examining how the current government has not only failed to improve on the misguided policies of previous administrations, but also as Ravitch says, has doubled down on policies of privatization, with disastrous consequences. 